\title{
Fat Digestion by Lingual Lipase: Mechanism of Lipolysis in the Stomach and Upper Small Intestine
}

\author{
TERESA H. LIAO, PAUL HAMOSH, AND MARGIT HAMOSH(65) \\ Department of Pediatrics and Department of Physiology and Biophysics, Georgetown University Medical Center, \\ Washington, D.C., USA
}

\section{Summary}

Ten to $30 \%$ of dietary fat is hydrolyzed in the stomach by lingual lipase, an enzyme secreted from lingual serous glands. We investigated the substrate specificity of this enzyme as well as the potential of lingual lipase to act in the upper small intestine i.e., in the presence of bile salts and lecithin. The data presented show that partially purified preparations of rat lingual lipase and the lipase in gastric aspirates of newborn infants have identical substrate specificity: medium-chain triglycerides were hydrolyzed at rates 5-8-fold higher than long-chain triglycerides; the rat and human enzymes do not hydrolyze the ester bond of lecithin or cholesteryl-ester. In contrast to pancreatic lipase, the hydrolysis of triglycerides by lingual lipase is not inhibited by lecithin. But, similar to pancreatic lipase the activity of lingual lipase is inhibited by bile salts, the extent of inhibition varying with its nature and concentration. This inactivation is not prevented by colipase but is partially averted by lipids and protein, suggesting that lingual lipase can remain active in the duodenum. The pH optimum of the enzyme (2.2-6.5 in the rat and 3.5-6.0 in human gastric aspirates) is compatible with continued activity in the upper small intestine, especially during the neonatal period, when the luminal $\mathrm{pH}$ is under 6.5. The marked variation in lipase activity levels in gastric aspirates of newborn infants is probably due to individual variations in enzyme amounts. The characteristics of the lipase are however identical in infants with low, intermediate or high activity levels. Our results indicate that hydrolysis of dietary fat by lingual lipase may not be limited to the stomach but may continue in the upper small intestine.

\section{Abbreviations}

CMC, critical micellar concentration

FFA, free fatty acid

Up to one-third of dietary fat is hydrolyzed in the stomach by lingual lipase $(21,27,28)$ an enzyme secreted from lingual serous glands $(23,27)$. Fat digestion in the stomach produces mainly partial glycerides and FFA, amphiphilic substances that help disperse the fat in the stomach and intestine (56). The gastric digestion of fat greatly enhances further hydrolysis of fat by pancreatic lipase in the small intestine $(6,45)$. Initial lipolysis in the stomach, a necessary step for normal fat absorption $(45,51)$, becomes a much more important process in conditions of physiologic or pathologic pancreatic insufficiency, such as prematurity $(22,37,61,63)$ or cystic fibrosis $(13,39)$. Recent studies show that the duodenal $\mathrm{pH}$ is significantly lower than normal in pancreatic insufficiency $(14,15)$ because of impaired bicarbonate secretion (20). In these cases lingual lipase, which hydrolyzes lipid in an acid environment ( $\mathrm{pH} 3.0-6.0$ ), could continue to act in the upper small intestine (13).

This study investigated the activity of lingual lipase under the conditions prevailing in the stomach and upper small intestine. The questions that we asked were the following: Does lingual lipase hydrolyze other dietary lipids such as lecithin and cholesteryl-ester? Is the hydrolysis of triglycerides inhibited by lecithin, as is the case with pancreatic lipase (41)? What is the effect of protein on enzyme activity? Because the enzyme might continue to act in the duodenum, what are the effects of bile salts and colipase on lingual lipase? To answer these questions we studied two enzyme preparations: partially purified rat lingual lipase (24) and the lipase present in human gastric aspirates, which closely resembles rat lingual lipase $(12,26)$.

\section{MATERIALS AND METHODS}

Lipase preparations. Rat lingual lipase was purified from homogenates of adult rat lingual serous glands as described previously (24).

Lipase in human gastric aspirates. Collection of infant gastric aspirates. Gastric aspirates were obtained from infants delivered at Georgetown University Hospital and its affiliation, Columbia Hospital for Women, in the delivery room as part of the routine neonatal care. These samples were frozen immediately and stored at $-70^{\circ} \mathrm{C}$ until analysis. Studies carried out during the last few years have shown that under these conditions, lipase activity is stable for several years.

Classification of gastric aspirates. The lipolytic activity of each gastric aspirate was screened on $20 \mu \mathrm{l}$ aliquots using a $\left[{ }^{3} \mathrm{H}\right]-$ triolein (C 18:1) emulsion at pH 4.2 and 8.1, as described previously (26). We previously established that at $\mathrm{pH} 4.2$ lingual lipase activity.is within the optimal range, whereas pancreatic lipase has no activity at this $\mathrm{pH}(26)$. Specimens with activity at $\mathrm{pH} 8.1$ (optimum for pancreatic lipase) were excluded from the study in order to avoid contamination of the gastric aspirates by pancreatic lipase, probably present in regurgitated duodenal contents. Gastric aspirates with lipolytic activity at $\mathrm{pH} 4.2$ from $330-660 \mathrm{nmol} \mathrm{FFA} \cdot \mathrm{ml}^{-1} \cdot \mathrm{min}^{-1}$ were classified as "low activity", activity from $661-995 \mathrm{nmol} \mathrm{FFA} \cdot \mathrm{ml}^{-1} \cdot \mathrm{min}^{-1}$ were classified as "intermediate activity", and activity from 996-1330 nmol FFA. $\mathrm{ml}^{-1} \cdot \mathrm{min}^{-1}$ were designated "high activity." Equal aliquots of gastric aspirate from samples of the same activity group were pooled and used throughout the study. Six samples of gastric aspirates were included in each group. About $20 \%$ of gastric aspirates had low activity, $50 \%$ intermediate activity, and $30 \%$ high lipase activity levels.

Preparation of lipid emulsions. Four lipid emulsions $\left[{ }^{3} \mathrm{H}\right]$ 
triolein (C 18:1, a long-chain triglyceride), $\left[{ }^{14} \mathrm{C}\right]$ tricaprylin (trioctanoin, C 8:0, a medium-chain triglyceride), $\left[{ }^{14} \mathrm{C}\right]$ dipalmitoyl lecithin (a phospholipid) and $\left[{ }^{14} \mathrm{C}\right]$ cholesteryl-oleate were used as substrates. The long-chain and medium-chain triglyceride emulsions were made by mixing $200 \mu \mathrm{mol}$ of unlabeled with labeled triolein ( $1 \mathrm{mCi} / \mu \mathrm{mol}$, Amersham, TRA-191, Arlington Heights, IL) or carrier and labeled $\left[{ }^{14} \mathrm{C}\right]$ carboxyl-tricaprylin $(10 \mathrm{mCi}$ ) mmol, New England Nuclear, NEC-195, Boston, MA) in chloroform. After evaporating the solvent, $3.3 \mathrm{ml}$ of anhydrous glycerol (J.T. Baker Chemical Co., 11-2136, Phillipsburg, NJ) was added and the mixture was sonicated in a polytron PCU-2110 sonifier (Brinkman Instruments, Westbury, NY) at setting 7 for 2 periods of $1 \mathrm{~min}$ each. To prepare the phospholipid emulsions, $100 \mu \mathrm{mol}$ of $\mathrm{L}-\alpha$-phosphatidyl choline (Sigma Chemical Co.) was evaporated under $\mathrm{N}_{2}$ to dryness at $55^{\circ} \mathrm{C}$. Then $0.2 \mathrm{ml}$ of absolute ethanol were added followed by $1.8 \mathrm{ml}$ of warm distilled water, added drop by drop. This emulsion was added to $1-\left[{ }^{14} \mathrm{C}\right]$ dipalmitoyl $\mathrm{L}$ - $\alpha$-phosphatidyl choline (Amersham, CFA604 ) which was first evaporated to dryness under $\mathrm{N}_{2}$, and mixed vigorously for several minutes. The cholesteryl-ester emulsion was made as follows. Two $\mu$ mols of cholesteryl-oleate was mixed with cholesteryl 1- $\left[{ }^{14} \mathrm{C}\right]$ oleate (New England Nuclear, NEC-638) and evaporated under $\mathrm{N}_{2}$ to dryness. The mixture was then dissolved in $0.2 \mathrm{ml}$ ethyl ether, $0.2 \mathrm{ml}$ water, and $10 \mu \mathrm{mol}$ of tauro-deoxycholate (Sigma Chemical Co.); then mixed and kept at $55-60^{\circ} \mathrm{C}$ for a few minutes. When the ether had evaporated, the suspension was sonicated in the Polytron sonifier at setting 5 for 2 periods of $1 \mathrm{~min}$ each. Two-tenths milliliters of water was added to the emulsion at $60^{\circ} \mathrm{C}$ and the emulsion was kept at that temperature for a few minutes. Fifty microliters of $25 \%$ bovine plasma albumin, pH 6.4 was then added and the mixture was made up to $1 \mathrm{ml}$ with water and sonicated again at setting 5 for 2 periods of $1 \mathrm{~min}$ each. The emulsion was heated to $50^{\circ} \mathrm{C}$ before use. The specific activity of the lipid substrates was 100,000 $200,000 \mathrm{dpm} / \mu \mathrm{mol}$. The lipid concentration in the triglyceride, lecithin and cholesteryl-ester emulsions was quantitated by the hydroxamic acid method of Rapport and Alonzo (47).

Assay of lipase activity. The assay system contained $1 \mu \mathrm{mol}$ of labeled lipid emulsion, $7 \mathrm{mg}$ of bovine plasma albumin (Fraction $\mathrm{V}$, Armour Pharmaceutical Co., Scottsdale, AZ), $10 \mu \mathrm{mol}$ of buffer, gastric aspirate or partially purified rat lingual lipase, and saline to bring the total volume to $200 \mu \mathrm{l}$. Incubation was at $37^{\circ} \mathrm{C}$ in a Dubnoff shaking bath. The reaction was stopped by the addition of a mixture of methanol:chloroform:heptane $(41: 1.25: 1.00, v / v / v)$. FFA were separated from the unhydrolyzed substrate by addition of $1.05 \mathrm{ml} 0.05 \mathrm{M}$ potassium carbonate buffer, $\mathrm{pH} 10(3)$. Aliquots $(0.5 \mathrm{ml})$ of the aqueous phase were transferred to $5 \mathrm{ml}$ Aquasure scintillation fluid (New England Nuclear, Boston MA) and the radioactivity was measured in a Beckman Scintillation Counter Model LS 7500 (Beckman Instruments, Inc., Fullerton, CA). For screening of the lipolytic activity of gastric aspirates, each specimen was analyzed at $\mathrm{pH}$ 4.2 and 8.1 , using sodium acetate-acetic acid buffer ( $\mathrm{pH} 4.2)$ and Tris-HCl buffer ( $\mathrm{pH} 8.1$ ).

Lipolytic activity towards each lipid substrate was measured with different amounts of gastric aspirates $(10-100 \mu \mathrm{l})$ or rat lingual lipase $(0.5-5 \mu \mathrm{g}$ protein) at $\mathrm{pH} 4.2$ and 5.4 with $50 \mathrm{mM}$ $\mathrm{Na}_{2} \mathrm{HPO}_{4}$-citric acid buffer. In addition, the $\mathrm{pH}$ optimum for the hydrolysis of the different lipid substrates was determined by varying the $\mathrm{pH}$ of the assay system from 2.0 to 9.0 (glycine $-\mathrm{HCl}$ buffer for the $\mathrm{pH}$ range $2.0-3.0$, sodium acetate-acetic acid buffer for the $\mathrm{pH}$ range 3.1-5.0, $\mathrm{Na}_{2} \mathrm{HPO}_{4}$-citric acid buffer for the $\mathrm{pH}$ range 5.1-7.2 and Tris- $\mathrm{HCl}$ buffer for the $\mathrm{pH}$ range 7.3-9.0). Experiments on the effect of bile salts-with and without procolipase, protein, or lipid on lingual lipase activity-were carried out in the lipase assay system described above, using a triolein emulsion described in detail previously $(24,26)$. Bile salts, purchased from the Calbiochem-Behring Corp. (American Hoechst Corp, San Diego, California), were of the highest purity commercially available.

\section{RESULTS}

Characteristics of rat lingual lipase. Effect of protein concentration on lipase activity. Digestion of fat in the stomach and intestine proceeds in the presence of large amounts of protein. It was therefore important to establish whether lipase activity is affected by protein. It is known that lipid hydrolysis by pancreatic lipase is markedly inhibited by even low concentrations of albumin which adsorb to the oil-water interphase thus preventing the interaction between enzyme and substrate (41). The data presented in Figure 1 show that the hydrolysis of triolein by lingual lipase increased $60 \%$ when albumin was added to the assay system at a final concentration of $1 \%$. Raising the albumin concentration from 1.0 to $3.7 \%$ led to only slightly higher lipolysis. Greater lipolysis in the presence of albumin is probably due to the efficient binding of the released FFA by albumin, thus preventing product inhibition of the enzyme. In order to establish whether lingual lipase might continue the hydrolysis of dietary fat in the upper small intestine, we have investigated the effect of $\mathrm{pH}$, procolipase, and bile salts on enzyme activity.

Effect of $\mathrm{pH}$ and procolipase on the activity of lingual lipase. The hydrolysis of triolein by partially purified rat lingual lipase was measured in the $\mathrm{pH}$ range of $2.2-8.0$ with and without purified porcine procolipase (a gift from Dr. J.S. Patton) (Fig. 2). The data show that lingual lipase has a broad optimal $\mathrm{pH}$ range from 2.2-6.4 and that the activity decreases sharply at pH 6.9 .

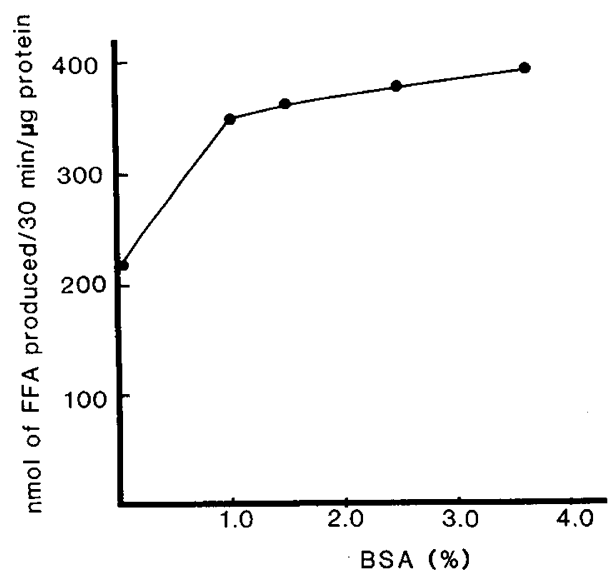

Fig. 1. Effect of albumin on lingual lipase activity. Albumin concentration in the assay system was increased from zero to $3.7 \%$.

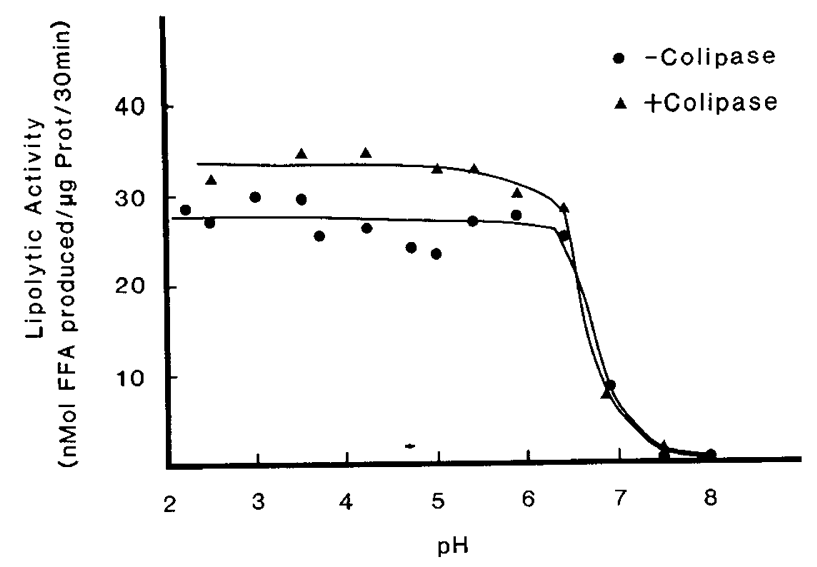

Fig. 2. Effect of colipase on triglyceride hydrolysis by lingual lipase. Purified colipase was a gift from Dr. J. S. Patton. Lipase activity was tested in the $\mathrm{pH}$ range $2.2-8.3$. The buffers were glycine- $\mathrm{HCl}$ for $\mathrm{pH} 2.2-$ 3.5 , sodium acetate-acetic acid for $\mathrm{pH} 3.7-5.8$, and phosphate buffer for pH 5.9-8.3. 
No lipase activity could be detected at $\mathrm{pH} 7.5$. The addition of procolipase ( $25 \mu \mathrm{g}$ protein per assay tube) led to a $25 \%$ increase in lipolytic activity in the $\mathrm{pH}$ range of 3.5-5.4. Colipase did not prevent the marked fall in activity above $\mathrm{pH} 6.4$.

Effect of bile salts on lipase activity. The data presented in Figure 3 show marked variation in the effect of different bile salts. Taurodeoxycholate and glycodeoxycholate inhibited the enzyme in the concentration range of $1.5-6.0 \mathrm{mM}$ whereas at higher concentrations $(6.0-25 \mathrm{mM})$ there was only slight (taurodeoxycholate) or marked (glycodeoxycholate) stimulation of lipolysis. The inhibitory effect of glycocholate and taurocholate (Figs. 4-6), on the other hand, was highest at concentrations of $6.0-15 \mathrm{mM}$ and, although at higher concentrations there was a return to normal activity, there was no stimulation of lipolysis. The maximal inhibitory effect of taurocholate was shifted from $6.0 \mathrm{mM}$ to $12 \mathrm{mM}$ in the presence of $3.75 \%$ albumin (Fig. 4). Increasing the substrate concentration from $1 \mu \mathrm{mol}$ in the assay mixture ( $5 \mathrm{mM}$, Figs. 3 and 4 ) to 2.5 and $10 \mu \mathrm{mol}(12.5$ and 50 $\mathrm{mM}$, respectively) (Fig. 5) did not diminish the inhibitory effect of taurocholate. At the highest triglyceride concentration, the maximal inhibitory range for taurocholate was wider $(6-18 \mathrm{mM})$ than at a lower triglyceride concentration (6-9 mM). The data suggest that the effect of bile salts on the activity of lingual lipase is modulated by other components of the diet such as fats and proteins. The inhibitory effect of bile salts on pancreatic lipase is prevented by colipase, a low molecular weight protein of pancreatic origin (8). We, therefore, investigated the effect of procolipase on the inhibition of lingual lipase by taurocholate (Fig. 6 ). The assay was carried out with and without $3.75 \%$ albumin. As we have seen in Figure 2, procolipase led to a slight increase in lipase activity, but had no effect on the inhibition of activity by taurocholate in the range of $3.0-30 \mathrm{mM}$. With the addition of $3.75 \%$ albumin, procolipase led to a greater increase in lipo- lytic activity. In the presence of albumin there was no inhibition of activity at low taurocholate concentrations (1.5-4.5 mM) and maximal inhibitory activity was shifted from 6 to $15 \mathrm{mM}$ (see also Fig. 4). Again, procolipase did not prevent the inhibition of lingual lipase by taurocholate (Fig. 6). The data show that procolipase, although slightly stimulating the activity of lingual lipase, could not prevent the inactivation of the enzyme by bile salts.

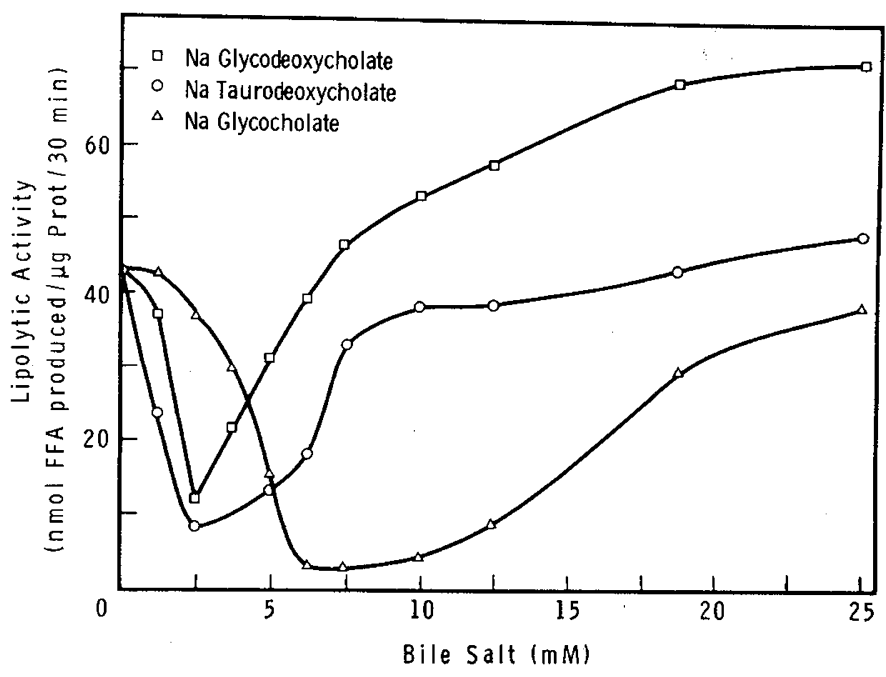

Fig. 3. Effect of bile salts on the activity of lingual lipase. The assay system contained $6 \mu \mathrm{g}$ enzyme protein per tube. Incubation was $30 \mathrm{~min}$ without albumin; substrate concentration, $1 \mu \mathrm{mol}$ triglyceride per tube.

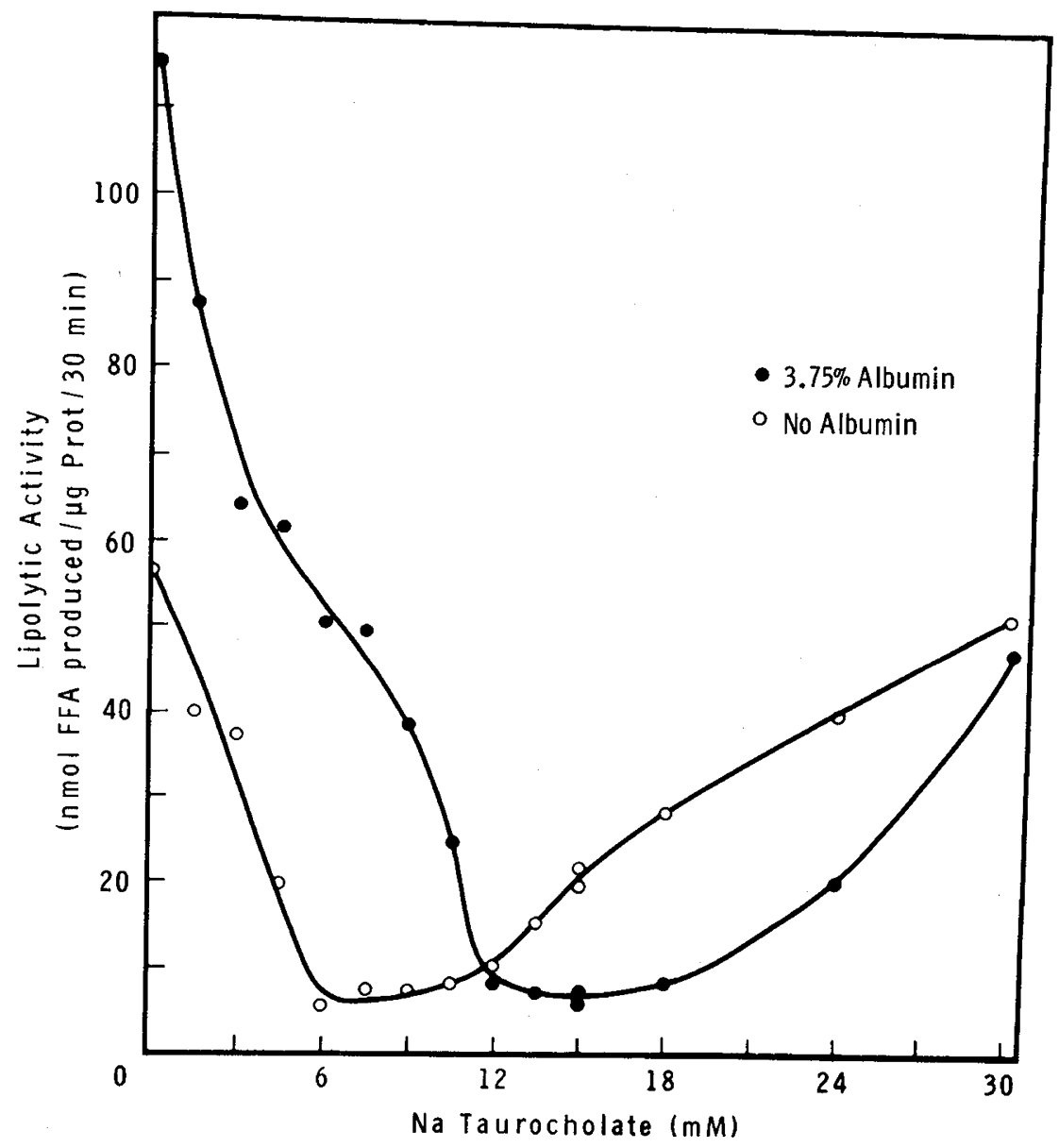

Fig. 4. Effect of albumin on the inhibition of lingual lipase activity by taurocholate. 
Substrate specificity of rat lingual lipase. Medium-chain triglycerides (C 8:0) were hydrolyzed by lingual lipase at rates 5-8 times higher than those of long-chain triglycerides (Fig. 7); however, the enzyme had no activity on phospholipids and cholesteryl-ester (Table 1). The hydrolysis of lecithin and cholesterylester was tested in the $\mathrm{pH}$ range $2.2-8.0$, with negative results at each $\mathrm{pH}$. The data indicate that lingual lipase activity is directed exclusively toward triglycerides, with a preference for mediumchain triglycerides. Contrary to pancreatic lipase, whose activity toward triglycerides is markedly inhibited by lecithin, the latter had no effect on the hydrolysis of triolein by lingual lipase (Table 2). Hydrolysis of triolein remained almost constant in the presence of various concentrations of lecithin (triolein:lecithin ratio, $1.0: 0.04$ to $1.0: 0.4$ ).

Characteristics of lipase in gastric aspirates of newborn infants. The aim of the studies presented in Figs. 8-10 and Tables 1 and 2 was to further characterize the lipase in gastric aspirates of newborn infants. We showed earlier (26) that: 1) lipase activity is present in gastric aspirates of infants born at 26-40 wk gestation, 2) the enzyme has a molecular weight similar to that of rat lingual lipase, and 3) bile salts affect it in a similar way to that reported for rat lingual lipase in the present study (Fig. 3). Our earlier study has shown that lipase levels fluctuate widely between individual infants from 10 to $1400 \mathrm{nmol}$ FFA released $\cdot \mathrm{ml}$ aspirate $^{-1} \cdot \min ^{-1}$ when triolein was used as substrate. In the present study we have compared the substrate specificity of rat lingual lipase with that of gastric aspirates of infants with low, intermediate, and high lipolytic activity levels.

Substrate specificity of the lipase in gastric aspirates of newborn infants. We divided the specimens arbitrarily into three groups: low activity $\left(330-660 \mathrm{nmol} \mathrm{FFA} \cdot \mathrm{ml}\right.$ aspirate $\left.{ }^{-1} \cdot \mathrm{min}^{-1}\right)$, intermediate activity $\left(661-995 \mathrm{nmol} \mathrm{FFA} \cdot \mathrm{ml}\right.$ aspirate $\left.^{-1} \cdot \mathrm{min}^{-1}\right)$ and high activity $\left(996-1330 \mathrm{nmol} \mathrm{FFA} \cdot \mathrm{ml}\right.$ aspirate $\left.{ }^{-1} \cdot \mathrm{min}^{-1}\right)$. The groups are based on the hydrolysis of triolein.

Figure 8 shows that irrespective of the level of lipolytic activity, hydrolysis of medium-chain triglycerides at $\mathrm{pH} 4.2$ proceeds at rates 6-8-fold higher than those of long-chain triglycerides. The effect of $\mathrm{pH}$ and albumin, the latter of which is an efficient acceptor for FFA acids released during lipolysis, on the hydrolysis of medium- and long-chain triglycerides is shown in Figure 9. The hydrolysis of triolein had a pH optimum of 3.5-5.5 with and without albumin in the assay system. The hydrolysis of trioctanoin proceeded at higher rates throughout the entire $\mathrm{pH}$ range tested (2.2-8.0). Activity on medium-chain triglyceride (without albumin in the assay mixture) had a slightly more alkaline optimum, 5.0-6.0. Addition of albumin stimulated lipolysis in the $\mathrm{pH}$ range $3-6$. The lipolytic activity in gastric aspirates of the high, intermediate, and low activity groups had identical $\mathrm{pH}$ optimum and preferred medium-chain triglyceride over long-chain triglyceride, suggesting that the three groups contain an identical lipase but probably had differing amounts of this lipase. As we have seen earlier with rat lingual lipase, the lipase in human gastric aspirates does not hydrolyze the ester bonds of lecithin or cholesteryl-ester (Table 1). The hydrolysis of these two lipids was checked in the $\mathrm{pH}$ range of 2.2-8.0 with negative results at all the $\mathrm{pH}$ levels tested. As with rat lingual lipase, lecithin did not inhibit the hydrolysis of triglyceridesboth medium- and long-chain species-by the lipase of human

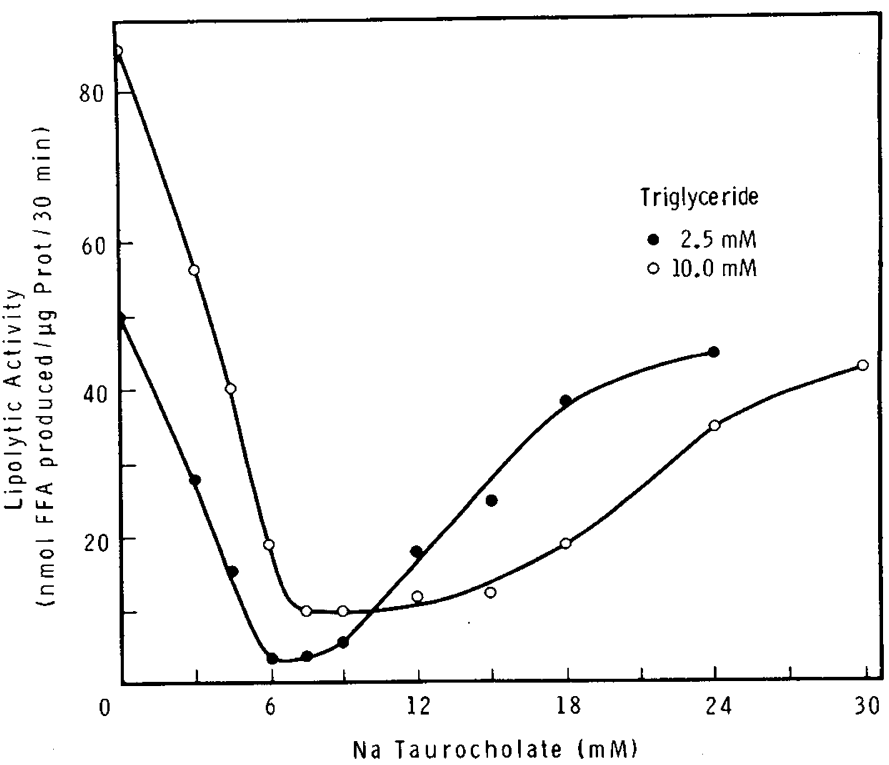

Fig. 5. Effect of bile salts on lingual lipase activity at different substrate concentrations. All conditions are similar to those described in the legend to Figure 3 except that the substrate concentration was 2.5 and $10.0 \mu \mathrm{mol}$ triglyceride per assay tube.

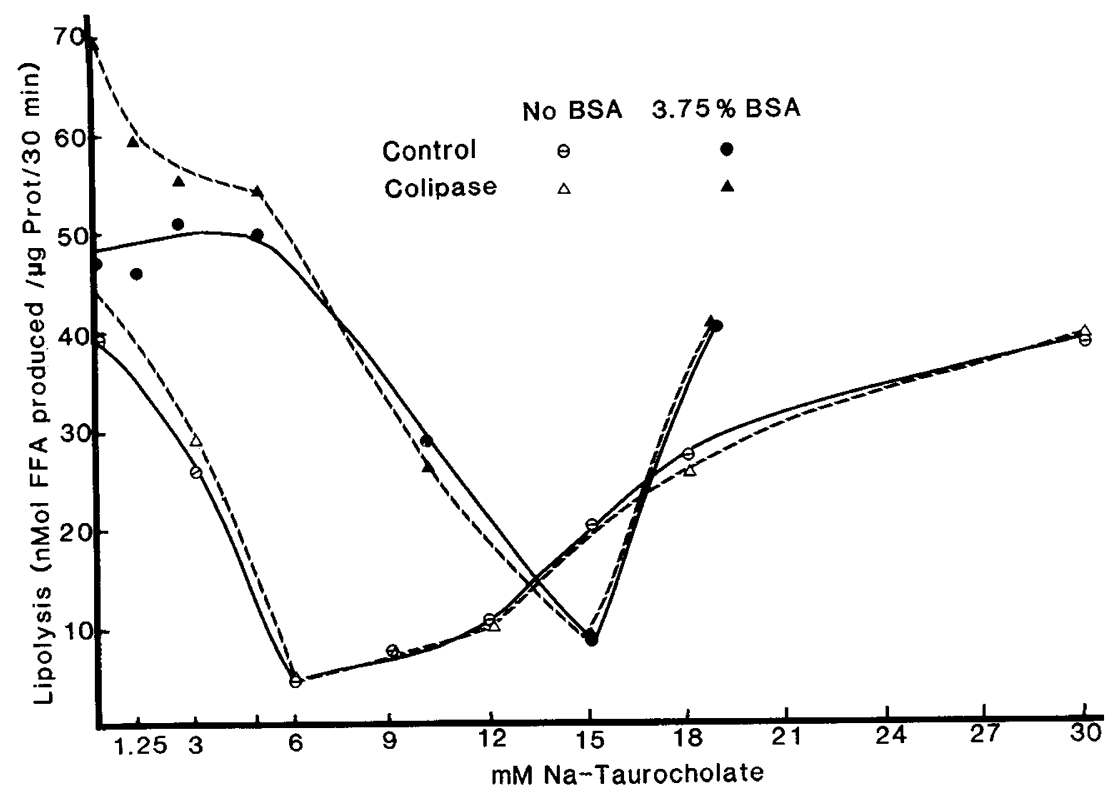

Fig. 6. Effect of colipase, in the presence or absence of albumin, on the inhibition of lingual lipase by taurocholate. Assay conditions the same as for Figure 3 (no albumin) or Figure 4 (with $3.5 \%$ albumin) Substrate concentration, $1 \mu$ mol triglyceride per assay tube. 


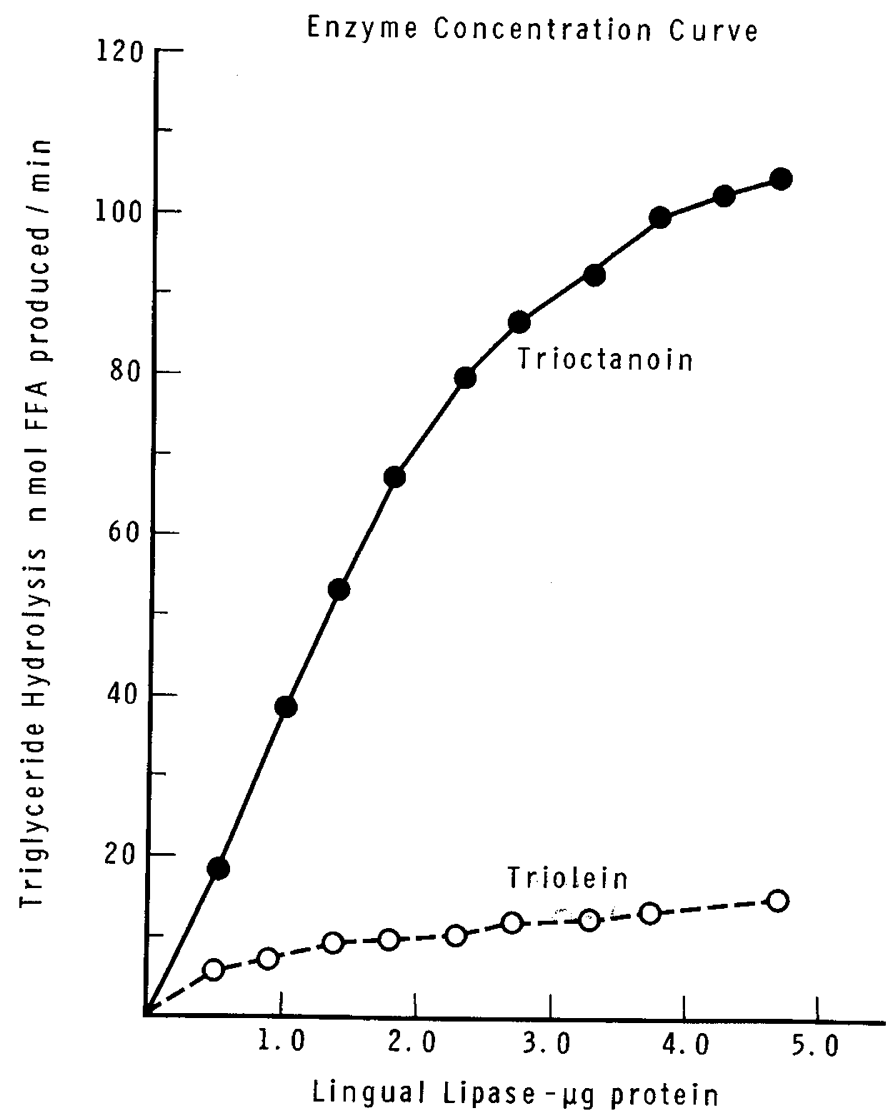

Fig. 7. Hydrolysis of medium- (C 8:0) and long- (C 18:1) chain triglyceride by rat lingual lipase. The assay system contained $1 \mu \mathrm{mol}$ of either tri $\left[{ }^{3} \mathrm{H}\right]$-olein or tri $1\left[{ }^{14} \mathrm{C}\right]$-octanoin. Incubation was for $30 \mathrm{~min}$.

Table 1. Substrate specificity of the lipase in infant gastric aspirates and of purified rat lingual lipase

\begin{tabular}{|c|c|c|c|c|}
\hline \multirow[b]{2}{*}{ Substrate } & \multicolumn{3}{|c|}{ Infant gastric aspirate* } & \multirow{2}{*}{$\begin{array}{c}\text { Rat } \\
\text { lingual } \\
\text { lipase } \ddagger \\
\text { (nmol } \\
\text { FFA } \\
\text { produced. } \\
\text { mg } \\
\text { protein. } \\
\text { min) }\end{array}$} \\
\hline & $\begin{array}{l}\text { High } \\
\text { activity } \dagger \\
\quad(\mathrm{nmo}\end{array}$ & $\begin{array}{l}\text { Med. } \\
\text { activity } \dagger \\
\text { FFA produ } \\
\text { spirate } \cdot \text { mir }\end{array}$ & $\begin{array}{l}\text { Low } \\
\text { activity } \dagger \\
\mathrm{d} \cdot \mathrm{ml}\end{array}$ & \\
\hline \multicolumn{5}{|l|}{ Triolein } \\
\hline $\begin{array}{l}\text { C 18:1 } \\
\text { Trioctanoin }\end{array}$ & 1067.5 & 686.3 & 418.3 & 11,420 \\
\hline $\begin{array}{l}\text { (Tricapry- } \\
\text { lin) } \\
\text { C } 8: 0\end{array}$ & 4665.0 & 2994.3 & 1973.5 & 37,060 \\
\hline $\begin{array}{c}\text { Phosphatidyl } \\
\text { choline }\end{array}$ & 0 & 0 & 0 & 0 \\
\hline $\begin{array}{c}\text { Cholesteryl } \\
\text { oleate }\end{array}$ & 0 & 0 & 0 & 0 \\
\hline
\end{tabular}

* Six samples of infant gastric aspirates with similar lipolytic activity were pooled for each series of lipase assay. FFA, free fatty acid.

$\uparrow$ High activity, pooled sample of gastric aspirates with lipolytic activity from $996-1330 \mathrm{nmol} \mathrm{FFA} \cdot \mathrm{ml}$ aspirate ${ }^{-1} \cdot \mathrm{min}^{-1}$. Med. activity, pooled sample of gastric aspirates with lipolytic activity from $661-995 \mathrm{nmol}$ FFA $\cdot \mathrm{ml}$ aspirate ${ }^{-1} \cdot \mathrm{min}^{-1}$. Low activity, pooled sample of gastric aspirates with lipolytic activity from $330-660 \mathrm{nmol} F F A \cdot m l$ aspirate ${ }^{-1}$. $\min ^{-1}$.

$\ddagger$ Partially purified rat lingual lipase, see "Materials and Methods."
Table 2. Effect of lecithin on the hydrolysis of triolein by rat lingual lipase*

\begin{tabular}{ccc}
\hline $\begin{array}{c}\text { Triolein } \\
(\mu \mathrm{mol})\end{array}$ & $\begin{array}{c}\text { Lecithin } \\
(\mu \mathrm{mol})\end{array}$ & $\begin{array}{c}\text { Lipase } \\
\text { activity } \\
(\mu \mathrm{mol} \mathrm{FFA} \\
\text { released } \cdot \mathrm{mg} \\
\left.\mathrm{protein}^{-1} \cdot \mathrm{min}^{-1}\right)\end{array}$ \\
\hline 1.0 & 0.40 & 4.70 \\
1.0 & 0.08 & 4.31 \\
1.0 & 0.04 & 4.12 \\
\hline
\end{tabular}

* The assay system contained in a final volume of $200 \mu \mathrm{l}, 1 \mu \mathrm{mol}$ triolein, various concentrations of lecithin and $0.85 \mu \mathrm{g}$ enzyme protein. FFA, free fatty acid.

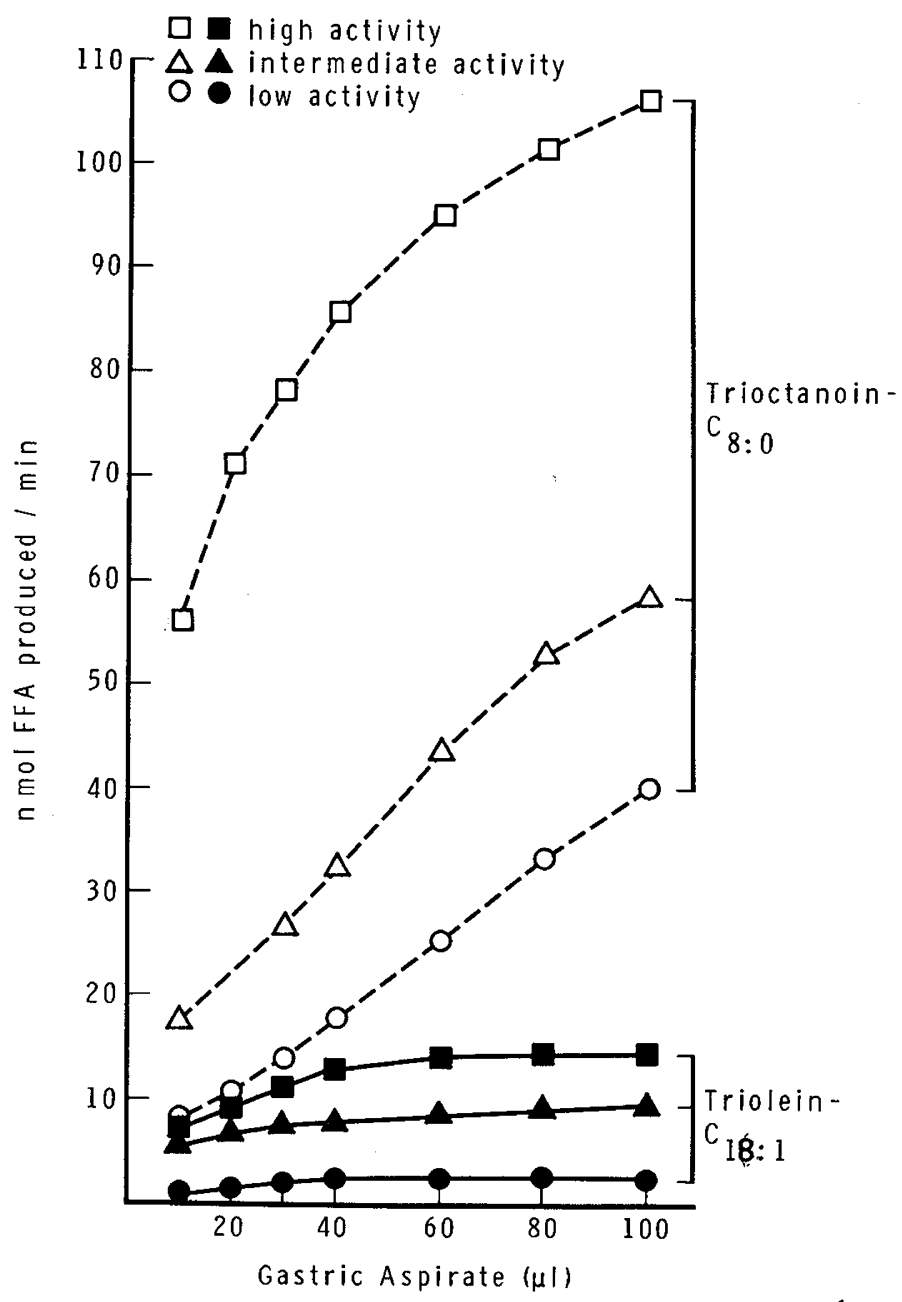

Fig. 8. Hydrolysis of medium- (C 8:0) and long- (C 18:1) chain triglyceride by the lipase in gastric aspirates of newborn infants. Substrates as described in the footnote to Figure 7. Lipolytic activity measured at pH 4.2. High lipolytic activity, 996-1330 nmol FFA released per ml aspirate/min; intermediate activity, 661-995 nmol FFA per ml aspirate/ $\mathrm{min}$; and low activity, 330-660 nmol FFA per $\mathrm{ml}$ aspirate/min.

gastric aspirates (Fig. 10). The hydrolysis of both triglyceride substrates proceeded at similar rates for $40 \mathrm{~min}$ in the presence or absence of high amounts of lecithin.

\section{DISCUSSION}

The data presented in this study further characterize and compare the activity of rat lingual lipase and the lipase of human 


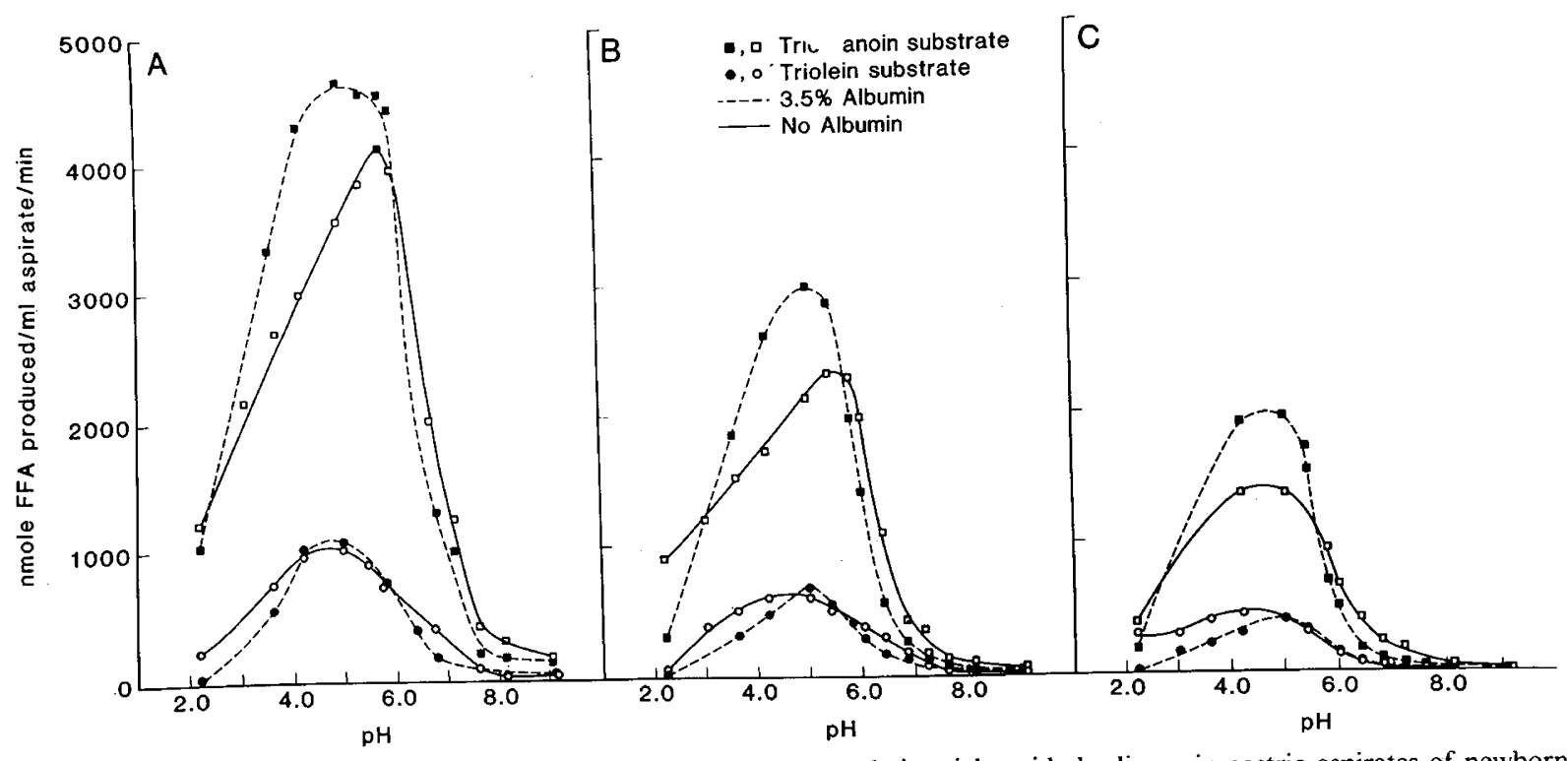

Fig. 9. Effect of $\mathrm{pH}$ and albumin on the hydrolysis of medium- and long-chain triglyceride by lipase in gastric aspirates of newborn infants. Panels $A, B$, and $C$ represent pooled specimens of gastric aspirates with lipolytic activity (toward triolein substrate) of 996-1330, 661-995, and 330$560 \mathrm{nmol} \cdot \mathrm{ml}$ aspirate ${ }^{-1} \cdot \mathrm{min}^{-1}$, respectively.

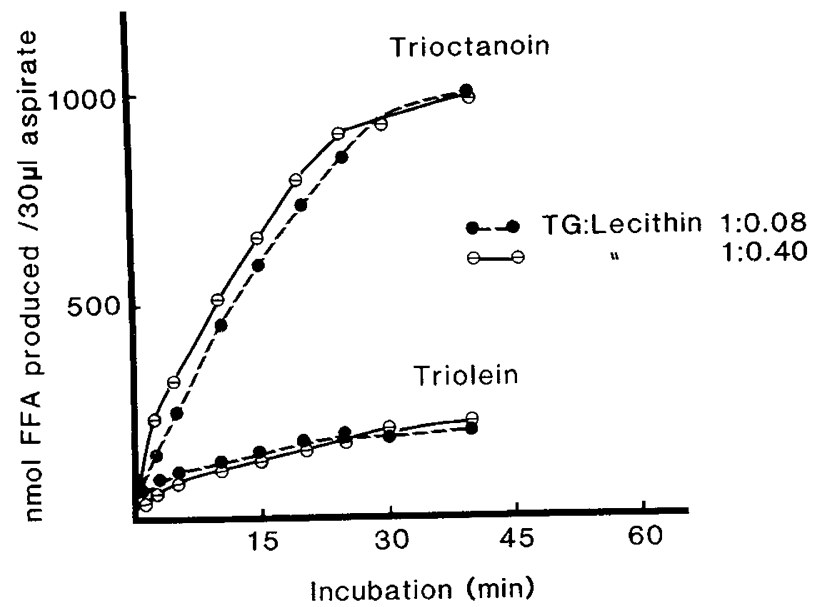

Fig. 10. Effect of lecithin on the hydrolysis of triglyceride by the lipase in gastric aspirates of newborn infants.

gastric juice. The results show marked similarity between the two species and indicate that the enzyme could act both in the stomach and in the intestine. Optimal activity of pancreatic lipase requires the presence of colipase and bile salts $(8,7,23)$. Furthermore, hydrolysis of triglycerides is inhibited by phospholipids (41) and protein (7) which prevent the action of pancreatic lipase at the oil/water interface. Lingual lipase seems to be a much less complex enzyme than pancreatic lipase (5-7), which would enable it to function under conditions that might not be compatible with pancreatic lipase activity.

Although it is well documented that lingual lipase is active in the stomach $(22,27,45,51)$, the data presented in this study indicate that the enzyme might continue to act in the upper small intestine. The acidic $\mathrm{pH}$ optimum for lipolysis, $2.2-6.5$ for rat lingual lipase (Fig. 2) and 3.5-6.0 for the lipase in human gastric juice (Fig. 9), allows the enzyme to act both in the stomach where the postprandial $\mathrm{pH}$ is $4.5-5.5(27,45)$ and in the intestine where the pH after ingestion of a test meal is 5.0-6.5 (14).

Lingual lipase, similarly to pancreatic lipase (7), is inhibited to various degrees by bile salts. Although pancreatic lipase is completely inhibited by bile salts above their CMC, lingual lipase exhibits low activity near the CMC. The extent of the inhibition of lingual lipase depends on the structure and concentration of each bile acid (Figs. 3 and 4). The inhibition cannot be prevented by procolipase (Fig. 6), as in the case of pancreatic lipase $(8,53)$, but is reduced by increasing the concentration of triglyceride and protein in the reaction mixture (Figs. 4 and 5). This suggests that lingual lipase might be protected from inactivation by bile salts by various components of the chyme, when the mixture of gastric contents enters the duodenum.

Indeed recent studies on the stability of lingual lipase (17) show that the enzyme is stable at low $\mathrm{pH}$ and could, thus, accumulate in the stomach between meals without loss of activity. Purified lingual lipase is stable for at least $1 \mathrm{~h}$ at $\mathrm{pH} 2.3$ and above whereas the lipase in human gastric juice is stable at even lower $\mathrm{pH}$ (1.6), indicating that other components present in the stomach might stabilize the enzyme. The inactivation at low $\mathrm{pH}$ can be prevented by lipids such as triglycerides or phospholipids, i.e., normal substrates of the enzyme as well as lipids that are not hydrolyzed by lingual lipase (Table 1). Lingual lipase, therefore, differs from pancreatic lipase in that the normal components of food, proteins, and phospholipids, stabilize the enzyme and enhance its activity (ref. 17 and Fig. 1) rather than inhibiting it as in the case of pancreatic lipase $(8,53)$. The same substances that prevent inactivation of lingual lipase at low stomach $\mathrm{pH}$, probably protect the enzyme from inactivation by bile salts in the intestine.

The role of non-pancreatic lipases in fat digestion and absorption has been recognized for more than a century $(60,62)$ although the nature of the lipolytic enzyme remained obscure. Recent animal studies show that diversion of oral secretions from the stomach by means of esophageal fistulas, causes a decrease not only in intragastric lipolysis, but also in the hydrolysis of fat in the intestine: $66 \%$ lower than normal in the duodenum and $30 \%$ lower in the jejunum and ileum (45). The lower fat digestion in animals with esophageal fistulas is accompanied by a marked rise in fat and bile salt excretion (51).

There is good evidence from both human and animal studies that as much as $70 \%$ of dietary fat can be absorbed in the absence of pancreatic lipase. Several earlier studies have shown that children with congenital or acquired absence of pancreatic lipase $(36,48,50,55)$ absorb as much as $70 \%$ of ingested fat. Studies in ruminants have shown that after diversion of pancreatic secretion from the intestine, $47 \%$ of milk fat entered the ileum digested to partial glycerides and FFA, compared to $60 \%$ in 
intact calves (18). Furthermore, $70 \%$ of long-chain triglycerides were absorbed in the absence of pancreatic juice. Data in ruminants show that this extent of fat hydrolysis is accomplished by pregastric esterase $(19,38,46)$, an enzyme of similar origin and characteristics as lingual lipase in rat (27) and man (23). Recent studies in patients with cystic fibrosis, who have complete absence of exocrine pancreatic function, show that $90 \%$ of the lipolytic activity measured at the ligament of Treitz, during both basal and postprandial conditions is that of lingual lipase (13). We can, therefore, assume that the digestion and absorption of $50-80 \%$ of ingested fat in this disease $(31,39)$ is dependent upon the activity of lingual lipase.

The lack of activity of lingual lipase on phospholipids and cholesteryl-ester (Table 1) suggests that these dietary fats have to be hydrolyzed by pancreatic enzymes $(5,35)$ and possibly by lipases or esterases of the intestinal mucosa $(11,54)$. Although, in vitro, the hydrolysis of medium-chain triglycerides proceeds at higher rates than that of long-chain triglyceride (Figs. 7-9), recent studies show that long-chain and medium-chain triglycerides in infant formulas are hydrolyzed to the same extent in the stomach of newborn infants (43). The discrepancy between in vitro activity, which is higher on medium-chain and shortchain triglycerides, and efficient hydrolysis of long-chain triglycerides in vivo, is thus common to both lingual and pancreatic lipase (49).

Lingual lipase is especially important for normal fat absorption in the newborn when milk fat is the major source of dietary lipid. Triglycerides (the major component of milk fat) are present in milk of humans and of other species as spherical droplets 2$3 \mu \mathrm{m}$ in diameter (4). The droplets contain a core of triglyceride and other non-polar lipids and an outer membrane composed of polar lipids, chiefly phospholipid and protein, derived mainly from the cell membrane during milk secretion (44). In the absence of colipase, milk fat globules are resistant to the action of pancreatic lipase $(12,45)$ but are readily hydrolyzed by lingual lipase $(27,45)$. Furthermore, preincubation with lingual lipase leads to a 20 -fold increase in the subsequent hydrolysis of the triglyceride in milk fat globules by pancreatic lipase (45). This effect could be due to alteration of the surface topography of the milk globule membrane during hydrolysis of its triglyceride core by lingual lipase. The products generated by lingual lipase, FFA and monoglycerides, being relatively polar, can locate in the surface layer (9). Their presence would dislocate proteins and phospholipids causing the underlaying triglyceride core to be more accessible to pancreatic lipase. Contrary to pancreatic lipase (which penetrates phospholipid-covered fat droplets only in the presence of colipase), lingual lipase is able to penetrate through the milk fat globule membrane. Our recent studies show that as much as $15 \%$ of human milk triglycerides can be hydrolyzed by lingual lipase without change in the microscopic appearance of the milk fat globules (43). Because lingual lipase has no activity against phospholipids (Table 1), we suggest that it can penetrate polar lipid membranes and hydrolyze the core triglyceride without hydrolyzing membrane lipid components. Furthermore, during the hydrolysis of milk fat droplets by lingual lipase, no visible liquid-crystalline product phases (as seen during triglyceride hydrolysis by pancreatic lipase (40), are formed. The products of lingual lipase activity, protonated fatty acids and diglyceride, appear to remain dissolved in the triglyceride core of the milk fat globule. This may be the reason why lingual lipase makes milk fat globules better substrates for pancreatic lipase $(12,45)$. Fatty acids increase lipase-colipase binding (42) and the binding of colipase to bile salts $(42,57)$. Furthermore, fatty acids in the oil phase enhance colipase binding to substrate and subsequent hydrolysis by pancreatic lipase (6). The reaction products formed during intragastric lipolysis by lingual lipase, not only aid the emulsification of fat in the stomach, but also enhance the affinity of pancreatic lipase and colipase for fat droplets thereby insuring the efficient digestion of fat in the duodenum.

The marked similarity in the characteristics of rat lingual lipase and the lipase in human gastric aspirates suggests that human lingual lipase (23) accounts for most of the activity in the gastric juice $(12,26,59)$. Although a lipase $(52,58)$ has been identified in the gastric mucosa of the rat by histochemical (2) and biochemical techniques $(10,32)$, it has been shown that this enzyme is specific for short- and medium-chain triglycerides and has no activity on long-chain triglycerides. Quantitation of gastric lipase from birth to adult age shows that in the rat, the activity amounts to only $1-5 \%$ of that of lingual lipase at all age periods studied (34). The very low activity of this enzyme suggests that it does not contribute significantly to the digestion of dietary fat in the stomach. It may, however, play a role in the absorption of medium-chain triglyceride-fatty acids through the gastric mucosa (1).

The early appearance of lingual lipase activity in the fetus (25, $26,34)$ and the marked rise in activity after birth suggest that the enzyme plays an important role in fat digestion in the newborn $(16,29)$, a period of high fat intake and immature pancreatic function (30). Lingual lipase, indeed, becomes the major digestive enzyme in diseases associated with chronic pancreatic insufficiency (13). We suggest, therefore, that lingual lipase, an important digestive enzyme under normal conditions, plays a major role in the digestion of fat in conditions associated with exocrine pancreatic insufficiency.

\section{REFERENCES AND NOTES}

1. Aw, T. Y. and Grigor, M. R.: Digestion and absorption of triacylglycerol in 14 day old suckling rats. J Nutr., 110: 2133 (1980).

2. Barrowman, J. W. and Darnton, S. J.: The lipase of rat gastric mucosa. A histochemical demonstration of the enzymatic activity against a medium chain triglyceride. Gastroenterology, 59: 13 (1970).

3. Belfrage, P. and Vaughan, M.: Simple liquid-liquid partition system for isolation of labeled oleic acid from mixtures with glycerides. J. Lipid Res., 10: 341 (1969).

4. Blanc, B: Biochemical aspects of human milk-comparison with bovine milk Word Res. Nutr. Diet, 36: 1 (1981).

5. Borgstrom, B.: On the interaction between pancreatic lipase and colipase and the substrate and the importance of bile salts. J. Lipid Res., 16: 411 (1975).

6. Borgstrom, B.: The importance of phospholipids, pancreatic phospholipase A2, fatty acid and other factors for the digestion of dietary fat: in vitro experiments with porcine enzymes. Gastroenterology, 78: 954 (1980).

7. Borgstrom, B. and Erlanson, C.: Interactions of serum albumin and other proteins with porcine pancreatic lipase. Gastroenterology, 75: 382 (1978).

8. Borgstrom, B., Erlanson-Albertsson, C., and Wieloch, T.: Pancreatic colipase chemistry and physiology. J. Lipid Res., 20: 805 (1979).

9. Bracco, V., Hildago, J., and Bohren, H.: Lipid composition of the fat globule membrane of human and bovine milk. J. Dairy Sci., 55: 165 (1972).

10. Clark, S. B., Brause, B., and Holt, P. R.: Lipolysis and absorption of fat in the rat stomach. Gastroenterology, 56:214 (1969).

11. Coates, P. M., Brown, S. A., Jumavan, J., and Koldovsky, O.: Characteristics and postnatal development of the acid lipase activity of the rat's small intestine. Biochem. J., 166: 331 (1977).

12. Cohen, M., Morgan, G. R. H., and Hofmann, A. F.: Lipolytic activity of human gastric and duodenal juice against medium and long-chain triglycerides. Gastroenterology, 60: 1 (1971).

13. Dutta, S. K., Hamosh, M., Abrams, C. K., Hamosh, P., and Hubbard, V. S. Quantitative estimation of lingual lipase activity in the upper small intestine in adult patients with pancreatic insufficiency. Gastroenterology, 82: 1047 (1982).

14. Dutta, S. K., Russell, R. M., and Iber, F. L.: Influence of exocrine pancreatic insufficiency on the intraluminal $\mathrm{pH}$ of the proximal small intestine. Am. J. Dig. Dis., 24: 529 (1979).

15. Dutta, S. K., Russell, R. M., and Iber, F. L.: Impaired acid neutralization in the duodenum in pancreatic insufficiency. Dig. Dis. Sci., 24: 775 (1979).

16. Fernando-Warnakulasurija, A. J. P., Staggers, J. E., Frost, S. C., and Wells, M A.: Studies on fat digestion absorption and transport in the suckling rat. I fatty acid composition and concentration of major lipid components. $J$. Lipid Res., 22: 668 (1981).

17. Fink, C. S., Hamosh, P., and Hamosh, M.: Fat digestion in the newborn: stability of lingual lipase in the stomach. Pediatr. Res., 18: (1984) (in press)

18. Gooden, J. M. and Lascelles, A. K.: Relative importance of pancreatic lipase and pregastric esterase in lipid absorption in calves 1-2 weeks of age. Aust. J. Biol. Sci., 26: 625 (1973).

19. Grosskopf, J. F. W.: Study on salivary lipase in young ruminants. Onderstepoort J. Vet. Res., 32: 153 (1965).

20. Hadorn, B., Zoppi, G., Shmerling, D. H., Prader, A., McIntyre, I., and Anderson, C. M.: Quantitative assessment of exocrine pancreatic function in infants and children. J. Pediatr., 73: 39 (1968).

21. Hamosh, M.: The role of lingual lipase in neonatal fat digestion. In: J. T. Harries: Development of Mammalian Absorptive Processes. Ciba Founda- 
tion Series 70. pp. 69-98 (Elsevier North-Holland Biomedical Press, Amsterdam, 1979)

22. Hamosh, M.: Lingual and breast milk lipases. In: L. A. Barness: Advances in Pediatrics. Vol 29. pp. 33-67 (Yearbook Medical Publisher, Chicago, 1982).

23. Hamosh, M. and Burns, W. A.: Lipolytic activity of human lingual glands (Ebner). Lab. Invest., 37:603 (1977).

24. Hamosh, M., Ganot, D., and Hamosh, P.: Rat lingual lipase: characteristics of enzyme activity. J. Biol. Chem., 254: 12121 (1979).

25. Hamosh $M$. and Hand, A. R.: Development of secretory activity in serous cells of the rat tongue. Develop. Biol., 65: 100 (1978).

26. Hamosh, M., Scanlon, J. W., Ganot, D., Likel, M., Scanlon, K. B., and Hamosh, P.: Fat digestion in the newborn. Characterization of lipase in gastric aspirates of premature and term infants. J. Clin. Invest., 67: 838 (1981).

27. Hamosh, M. and Scow, R. O.: Lingual lipase and its role in the digestion of dietary fat. J. Clin. Invest., 52: 88 (1973).

28. Hamosh, M. and Scow, R. O.: Plasma triglyceride and lipoprotein lipase activity in pregnant and lactating rats. Excerpta. Medica. (ICS No. 213), 207. $211(1970)$.

29. Helander, H. F. and Olivecrona, T.: Lipolysis and lipid absorption in the stomach of the suckling rat. Gastroenterology, 59: 22 (1970).

30. Koldovsky, O.: Development of function of the small intestine in mammals and man. (Karger, Basel, 1969).

31. Lapey, A., Kattwinkel, J., di Sant'Agnese, P. A., and Laster, L.: Steatorrhea and azotorrhea and their relation to growth and nutrition in adolescents and young adults with cystic fibrosis. J. Pediatr., 84: 328 (1974).

32. Levy, E., Goldstein, R., Freir, S., and Shafrir, E.: Characterization of gastric lipolytic activity. Biochim. Biophys. Acta., 664: 316 (1981).

33. Liao, T. H., Buczek, R. J., Mehta, N. R., Grylack, L. J., Hamosh, P., and Hamosh, M. Fat digestion in the stomach: hydrolysis of formula triglyceride by premature infants. Clin. Res., 31:285A (1983).

34. Liao, T. H., Hamosh, M., and Hamosh, P.: Development of preduodenal fat digestion in the rat. Fed. Proc., 41: 103 (1982).

35. Lombardo, D., Guy, O., and Figarella, C.: Purification and characterization of a carboxylester hydrolase from human pancreatic juice. Biochim. Biophys. Acta., 527: 142 (1978).

36. Muller, D. P. R., McCollum, J. P. K., Trompeter, R. S., and Harries, J. T.: Studies on the mechanism of fat absorption in congenital lipase deficiency. Gut, 16: 838 (1975).

37. Norman, A., Strandvik, B., and Ojamae, O.: Bile acids and pancreatic enzymes during absorption in the newborn. Acta. Pediatr. Scand., 61: 571 (1972)

38. Otterby, D. E., Ramsey, H. A., and Wise, G. A.: Lipolysis of milk fat by pregastric esterase in the abomasum of the calf. J. Dairy Sci., 47: 993 (1964).

39. Park, R. W. and Grand, R. J.: Gastrointestinal manifestations of cystic fibrosis: a review. Gastroenterology, 81: 1143 (1981).

40. Patton, J. S. and Carey, M. C.: Watching fat digestion. Science, 204: 145 (1979).

41. Patton, J. S. and Carey, M. C.: Inhibition of human pancreatic lipase-colipase activity by mixed bile salt-phopholipid micelles. Am. J. Physiol., 241: G328 (1981).

42. Patton, J. S., Donner, J., and Borgstrom, B.: Lipase-colipase interactions during gel filtration, high and low affinity binding situations. Biochim. Biophys. Acta, 529: 67 (1978).

43. Patton, J. S., Rigler, M. W., Liao, T. H., Hamosh, P., and Hamosh, M.: Hydrolysis of triacylglycerol emulsions by lingual lipase-a microscopic study. Biochim. Biophys. Acta, 712: 400 (1982).

44. Patton, S. and Jensen, R. G.: Biomedical aspects of lactation. (Oxford, Pergamon Press, 1975)
45. Plucinski, T. M., Hamosh, M., and Hamosh, P.: Fat digestion in the rat: role of lingual lipase. Am. J. Physiol., 237: E541 (1979).

46. Ramsey, H. A. and Young, J. W.: Role of pregastric esterase in the abomosal hydrolysis of milk fat in the young calf. J. Dairy Sci., 44: 2227 (1961).

47. Rapport, M. M. and Alonzo, N.: Photometric determination of fatty acid ester groups in phospholipids. J. Biol. Chem., 217: 193 (1959).

48. Rey, J., Frezal, F., Royer, P., and Lamy, M.: L'absence congenitale de lipase pancreatique. Arch. Fr. Pediatr., 23: 5 (1966).

49. Roberts, I. M., Montgomery, R. K., and Carey, M. C.: Lingual lipase hydrolyzes triglycerides in the presence of lecithin and bile salt micelles. Gastroenterology, 82: 1163 (1982).

50. Ross, C. A. C. and Sammons, H. C.: Non pancreatic lipase in children with pancreatic fibrosis. Arch. Dis. Child., 30: 428 (1955).

51. Roy, C. C., Roulet, M., Lefebre, D., Chartrand, L., Lepage, C., and Fournier, L. A.: The role of gastric lipolysis in fat absorption and bile acid metabolism in the rat. Lipids, 14:811 (1979).

52. Schonheyder, F. and Volqvartz, K.: The gastric lipase in man. Acta Physiol. Scand., 11: 349 (1946).

53. Semeriva, M. and Desnuelle, P.: Pancreatic lipase and colipase an example of heterogeneous biocatalysis. Adv. Enzymol., 48: 319 (1979).

54. Serrero, G., Negrel, R., and Ailhaud, G.: Characterization and partial purification of an intestinal lipase. Biochim. Biophys. Res. Commun., 65: 89 1975).

55. Sheldon, W.: Congenital pancreatic lipase deficiency. Arch. Dis. Child., 39: 268 (1964).

56. Small, D. M.: A classification of biologic lipids based upon their interaction in aqueous systems. J. Am. Oil Chem. Soc., 45: 108 (1968).

57. Suave, $P$. and Desnuelle, P.: Interactions of pancreatic colipase with taurodeoxycholate-oleate mixtures above the critical micelle concentration. FEBS Lett., 122: 91 (1980).

58. Szafran, H., Szafran, Z., Popiela, T., and Wanicka, A.: Electrophoretic properties and specificity of human gastric lipase. Enzyme, 23: 187 (1978).

59. Tiruppathi, C. and Balasubramanian, K. A.: Purification and properties of an acid lipase from human gastric juice. Biochim. Biophys. Acta, 712: 692 (1982).

60. Volhard, F.: Über das fettspaltende Ferment des Magens. Z. Klin. Med., 42 414 (1901).

61. Watkins, J. B., Ingall, D., Szezcepanik, P., Klein, P. D., and Lester, R.: Bile salt metabolism in the newborn infant. Measurement of pool size and synthesis by stable isotopic technique. N. Engl. J. Med., 288: 431 (1973).

62. Wills, E. D.: Lipases. Adv. Lipid Res., 3: 197 (1975).

63. Zoppi, G., Andreoti, G., Pajno-Ferrara, F., Njai, D. M., and Gaburro, D. Exocrine pancreas function in premature and full-term neonates. Pediatr. Res., 6: 880 (1972).

64. This study was presented in part at the annual meetings of the American Federation for Clinical Research. San Francisco, April, 1981, and Washington, DC, May 1982 and published in abstract form (Clin Res 29:309A, 1981, and Clin. Res. 30:279A, 1982)

65. Requests for reprints should be addressed to: Dr. Margit Hamosh, Department of Pediatrics, Georgetown University Medical Center, 3800 Reservoir Road, NW, Washington, D.C. 20007.

66. This research was supported by National Institutes of Heaith Grant HD-10823. We thank Dr. J. W. Scanlon and Mrs. K. B. Scanlon for providing gastric aspirates from newborn infants. The expert secretarial help of Ms. Marguerite Starry is greatly appreciated.

67. Received for publication April 19, 1983.

68. Accepted for publication August 10, 1983 . 